ORNL/CON-483

\title{
THE OPTIONS FOR WEATHERIZATION PROGRAMS IN THE NOx TRADABLE EMISSION PERMIT PROGRAM
}

\author{
Anjali T. Chen \\ Aspen Systems Corp. \\ Donald W. Jones \\ Energy Division \\ Oak Ridge National Laboratory
}

March 2001

OAK RIDGE NATIONAL LABORATORY

Oak Ridge, Tennessee 37831

managed by

UT-BATTELLE, PLC

for the

U.S. DEPARTMENT OF ENERGY

under contract No. DEAC05-00OR22725 



\section{TABLE OF CONTENTS}

EXECUTIVE SUMMARY $\ldots \ldots \ldots \ldots \ldots \ldots \ldots \ldots \ldots \ldots \ldots \ldots \ldots$ ii

LIST OF TABLES $\ldots \ldots \ldots \ldots \ldots \ldots \ldots \ldots \ldots \ldots \ldots \ldots \ldots \ldots \ldots \ldots \ldots \ldots$

LIST OF ACRONYMS $\ldots \ldots \ldots \ldots \ldots \ldots \ldots \ldots \ldots \ldots \ldots \ldots \ldots \ldots \ldots \ldots$

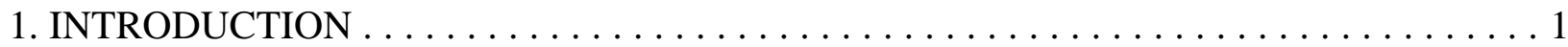

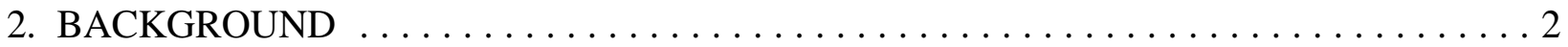

3. THE NOx SIP CALL AND THE EE/RE SET-ASIDE $\ldots \ldots \ldots \ldots \ldots \ldots \ldots \ldots \ldots \ldots \ldots$

3.1 IMPLEMENTING THE EE/RE SET-ASIDE $\ldots \ldots \ldots \ldots \ldots \ldots \ldots \ldots \ldots \ldots$

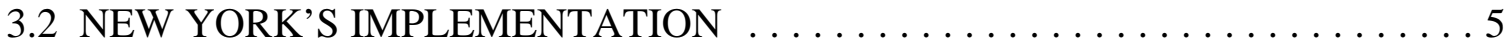

4. NOx EMISSIONS REDUCTIONS AND WEATHERIZATION $\ldots \ldots \ldots \ldots \ldots \ldots \ldots \ldots 7$

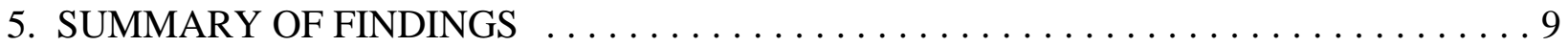

6. STATE WEATHERIZATION PROGRAMS' BENEFITS IN THE NOx TRADABLE PERMIT PROGRAM: OPPORTUNITIES AND LIMITATIONS $\ldots \ldots \ldots \ldots \ldots \ldots \ldots \ldots$

Appendix I: Nitrogen Oxide (NOx) Emissions Savings for a Full Year . . . . . . . . . . . 13

Appendix II: Methodology for Calculation of Nitrogen Oxide Emissions $\ldots \ldots \ldots \ldots \ldots$

Appendix III: Number of Homes Weatherized in $1998 \ldots \ldots \ldots \ldots \ldots \ldots \ldots$ 


\section{EXECUTIVE SUMMARY}

In September 1998, the U.S. Environmental Protection Agency (EPA) promulgated a rule to address the regional transport of ground-level ozone by reducing nitrogen oxide (NOx) emissions in states that were contributing significantly to air pollution problems for downwind states. One element of this program is a NOx tradable emission rights system, to be implemented by individual states. Large, stationary emission sources such as utilities and large cement plants will be issued certain quantities of emission rights, but EPA has encouraged states to set aside some proportion of these rights for energy-efficiency and renewable energy (EE/RE) programs, which could sell rights and use the proceeds to further support their programs. States have considerable leeway in specifying which EE/RE programs will receive emission rights. The U.S. Department of Energy's (DOE) Weatherization Assistance Program wanted to know whether the funding that could be derived from the sale of NOx emission rights would be large enough to justify the effort of verifying NOx reductions from its weatherization activities.

This study projected the scope for NOx emission reductions from electricity-intensive weatherization measures in the twenty-two states, and the District of Columbia, included in the EPA ruling. The twenty-two states covered by the rule could expect from $\$ 6,000$ to $\$ 66,000$ per year from sale of NOx permits (at an average sale price of $\$ 3,000 /$ ton), amounts which correspond to $0.08 \%$ to $0.25 \%$ of annual state weatherization expenditures in 1998 . Some states may find the prospective revenues large enough to justify the cost of providing savings verification to state environmental agencies, and others may not. 


\section{LIST OF TABLES}

Table 1: Nitrogen Oxide (NOx) emissions saved in homes weatherized in $1998 \ldots \ldots \ldots$. . . 8

Table 2. Financial benefits to State Weatherization Programs from NOx permit sales . . . . . 11 


\section{LIST OF ACRONYMS}

$\begin{array}{ll}\text { AEO } & \text { Annual Energy Outlook } \\ \text { BAU } & \text { Business as usual } \\ \text { Btu } & \text { British thermal unit } \\ \text { DOE } & \text { U.S. Department of Energy } \\ \text { EE } & \text { Energy efficiency } \\ \text { EE/RE } & \text { Energy efficiency and renewable energy } \\ \text { EGU } & \text { Electrical generating unit } \\ \text { EIA } & \text { Energy Information Administration } \\ \text { EPA } & \text { U.S. Environmental Protection Agency } \\ \text { ESCO } & \text { Energy service company } \\ \text { M\&V } & \text { Measurement and verification } \\ \text { MOU } & \text { Memorandum of understanding } \\ \text { NASEO } & \text { National Association of State Energy Officials } \\ \text { NEMS } & \text { National Energy Modeling System } \\ \text { NERC } & \text { National Electric Reliability Council } \\ \text { NYSDEC } & \text { New York State Department of Environmental Conservation } \\ \text { NYSERDA } & \text { New York State Energy Research and Development Authority } \\ \text { NOx } & \text { Nitrogen oxides } \\ \text { ORNL } & \text { Oak Ridge National Laboratory } \\ \text { OTAG } & \text { Ozone Transport Assessment Group } \\ \text { OTC } & \text { Ozone Transport Commission } \\ \text { OTR } & \text { Ozone Transport Region } \\ \text { RACT } & \text { Reasonably available control technology } \\ \text { SIP } & \text { State Implementation Plan } \\ \text { T\&D } & \text { Transmission and distribution }\end{array}$




\section{INTRODUCTION}

In September 1998, the U.S. Environmental Protection Agency (EPA) promulgated a rule to address the regional transport of ground-level ozone, or smog, by reducing nitrogen oxide (NOx) emissions in states which were contributing significantly to air pollution problems for "downwind" states. NOx reacts in the atmosphere to form compounds that contribute to the formation of ozone. Because these compounds, as well as ozone itself, can travel hundreds of miles across state boundaries to affect public health in areas far from the source of the emissions, cities with 'clean' air - those that meet or attain the national air quality standards for ozone-may be contributing to a downwind city's ozone problem because of transport. The EPA rule (commonly known as the NOx SIP Call) required revised state implementation plans (SIPs) for NOx emissions reductions from 22 eastern states and the District of Columbia by September 1999 to combat ozone transport.

One characteristic of the NOx SIP Call that distinguishes it from other multi-state efforts to reduce NOx emissions is a set-aside in each state's NOx budget for energy-efficiency and renewable energy (EE/RE) programs. A state's NOx budget is the total amount of NOx the state is allowed to emit. The state's historic emitters, primarily electric utilities and industrial boilers, are allocated a certain number of NOx allowances that, in total, make up the state's NOx budget. Each NOx allowance permits a source to emit one ton of NOx during the control period of May 1 through September 30 (the "summer ozone season"). If a polluter exceeds the allotted NOx emissions, then the polluter must purchase NOx allowances in the tradeable emissions market to account for the excess emissions of NOx.

Because state weatherization programs reduce NOx emissions through their energy-efficiency programs, they could become eligible contenders for the state's NOx allowances, but only the NOx reductions during the summer ozone season count in the permit allocation. The U.S. Department of Energy's (DOE) Weatherization Assistance Program, and the various state programs, could apply to the state agency administering the allocation of NOx allowances for allowances based on the amount of NOx their programs have reduced. These allowances, if sold on the open market for NOx emissions trading (generally to utilities and others exceeding their quota of NOx emissions and thus needing to buy allowances),would generate a certain amount of money. This paper explores the question of whether the amounts of funds so generated would make it worthwhile for the Weatherization Assistance Program to apply for NOx allowances. This is done by calculating NOx emission savings brought about by weatherization in the states affected by the NOx SIP Call.

After the SIP Call was issued, several of the states and some utilities challenged EPA's action. On May 25, 1999, the U.S. Court of Appeals granted a motion to temporarily stay the deadlines for state submittals established in the NOx SIP Call pending further judicial action. The Court, which began hearing the case in November 1999, came out with its decision in March 2000 confirming EPA's authority to compel states to clamp down on their NOx emissions. It did, however, exclude Wisconsin, Georgia and Missouri. Thus the District of Columbia plus the following 19 states are now compelled to respond to the SIP Call: Alabama, Connecticut, Delaware, Illinois, Indiana, Kentucky, Massachusetts, Maryland, Michigan, New Jersey, New York, North Carolina, Ohio, Pennsylvania, Rhode Island, South Carolina, Tennessee, Virginia, and West Virginia.

\section{BACKGROUND}


Some knowledge of the history of NOx emission reduction programs in the U.S. can be helpful in understanding how the evolving market in NOx emissions functions. It also offers context for the political nature of the program.

The implementation of reasonably available control technology (RACT) for automobile assembly plants in ozone non-attainment areas was considered Phase I of this process. Phase II was initiated in September 1994, when the Ozone Transport Commission (OTC) adopted a Memorandum of Understanding (MOU) committing the eleven signatory states (Maine, New Hampshire, Vermont, Massachusetts, Connecticut, Rhode Island, New York, New Jersey, Pennsylvania, Maryland and Delaware), the District of Columbia, and the northern counties of Virginia (the state of Virginia was not a signatory) to the development and proposal of region-wide NOx emissions reductions in 1999 and 2003. The program capped NOx emissions at 219,000 tons in 1999 and 143,000 tons in 2003, less than half the of the 1990 baseline emission level of 490,000 tons.

In January 1996, the OTC released the NOx Budget Model Rule, based on a consensus among the states and the EPA. This provided state regulatory agencies with a common framework for emissions monitoring, record-keeping and reporting requirements for NOx budget sources, permitting the creation of an integrated interstate emissions trading program based on market forces.

Phase II compliance began in May 1999 with the operation of the ozone-related NOx Budget Program in the Ozone Transport Region (OTR), set in motion by EPA and the northeastern states. Phase III, which would begin in May 2003 to be in compliance by September 2007, is the focus of the NOx SIP Call.

Under this program, the total allowable NOx budget in that region is divided among the participating states. Each state government then allocates allowances to each of its budget sources, primarily electric utilities and industrial boilers. In addition to the budget sources identified in the MOU, states have the option of subjecting other source categories to the program. Other stationary sources also have the option of voluntarily complying with the program (i.e., opt-in) on an individual basis. Each NOx allowance permits a source to emit one ton of NOx during the control period for which it is allocated or any later control period. For each ton of NOx discharged in a given control period, one allowance is retired and can no longer be used. NOx allowances may be bought, sold or banked. Any person may acquire allowances and participate in the trading system. Each budget source must comply with the program by demonstrating at the end of each control period that actual emissions do not exceed the amount of allowances held for that period (EPA 1997).

In the meantime, the Ozone Transport Assessment Group (OTAG), which comprises the 37 eastern-most states, met from 1995 to 1997 attempting to arrive at a consensus on strategies for controlling NOx emissions in the region, primarily for Phase III of the MOU which was set to begin in May 2003. While they failed to reach agreement, they did undertake and complete a considerable amount of modeling on NOx emissions in the region, and made recommendations that subsequently formed the basis of the NOx SIP Call. 


\section{THE NOx SIP CALL AND THE EE/RE SET ASIDE}

Under the terms of the NOx SIP Call, EPA would allocate NOx emission allowances on a state-by-state basis that will comprise each state's NOx budget for the summer months of any given year (May through September). The NOx Trading Program Budget-already underway within the OTC region and probably expanding to include the SIP Call region-would then permit the trading of these allowances allocated according to the reduction of NOx emissions. The Budget has two components: 1) an electricity budget, and 2) a fuel budget. The electricity budget is based on tons of emissions allowable for a group of core sources that comprise all large fossil fuel-fired stationary boilers, combustion turbines and combined cycle systems that serve electrical generating units (EGU) of greater than $25 \mathrm{MWe}$ capacity. The fuel budget is based on the same group of core sources that serve non-electrical generating units.

The EE/RE set-aside of approximately 5-15\% comes from within a state's NOx budget for core sources that generate electricity. The set-aside comes from within a state's budget in order to ensure that the use of the allowances does not result in the state exceeding its NOx budget. While a 5-15\% set-aside is recommended by EPA, the exact percentage decided upon is at the discretion of each state. Energy programs that can show NOx emissions reductions can then apply for the applicable number of NOx allowances to the relevant state agency (EPA 1999). The NOx allowances would be awarded to the authorized account representative of the energy program deemed eligible. This program could then sell it on the open market for NOx allowances. For example, Massachusetts' EGU maximum number of allowable NOx tons in the summer months is 14, 619 tons. Since $15 \%$ of this amount would be 2,218 tons, the maximum number of NOx allowances that EE/RE programs in Massachusetts can then apply for are 2218 allowances (EPA 1999).

\subsection{IMPLEMENTING THE EE/RE SET-ASIDE}

EPA recommends that all EE/RE projects meet the following seven criteria before being deemed eligible for NOx allowances:

- $\quad$ reduce/displace electricity load from core source EGUs in the SIP Call region;

- $\quad$ not be required by Federal government regulation;

- not/will not be used to generate compliance or permitting credits elsewhere in the SIP;

- $\quad$ be in operation in the year(s) for which it will receive allowances;

- $\quad$ reduce/displace energy during the summer ozone season;

- $\quad$ be measured and verified in accordance with methods outlined in EPA's guidance document; and

- translate into not less than one (1) ton of NOx allowances, or can be aggregated with other projects into one-ton increments of NOx allowances.

Thus entities such as residential aggregators, ESCOs, and large industrial and commercial customers are envisioned as the likely recipients of the set-aside allowances. They will benefit through the sale of the allowances back into the NOx market that electricity generators may need to 
buy in order to comply with their NOx emissions allocations. Because the trading of NOx allowances is a relatively recent phenomenon, experience with NOx allowance prices and price forecasting has not been extensive. Early experience in the Northeast indicates considerable fluctuation in prices. Trading began at around $\$ 1,900$ per ton last spring, but has gone up to as much as $\$ 7,500$ per ton recently (Letzelter and Chupka 1999). EPA estimates an average allowance price of approximately $\$ 3,000$ per ton (Letzelter and Chupka 1999).

How allowances will be awarded under the EE/RE set-aside, and the size of the set-aside, will depend on each state and on what types of projects it wants to encourage. Therefore, it will depend to a large extent on the ways in which the program design issues are resolved in each state. Some of the issues raised by EPA are (EPA 1999):

- $\quad$ who and what is eligible to be awarded the allowances;

- $\quad$ whether to focus on "new" projects and not on projects that are already in place;

- $\quad$ whether or not a state will award allowances for early actions (i.e. actions before 2003);

- the length of an award, which translates into the number of control periods the award will be given for; and

- $\quad$ how to make adjustments in the size of a state's set-aside to fit the level of demand it achieves once it has been implemented (over and under-subscription of the allowance pool).

In the case of who and what will be eligible for allowances from the set-aside, EPA suggests that the larger the universe of potential projects that could be awarded allowances, the larger the number of allowances the state needs to set aside in its overall pool of allowances to accommodate these projects. If, on the other hand, the state sets a narrower scope of eligible projects, then the state can set fewer allowances aside for EE/RE projects.

"New" projects are defined here as those that deliver additional energy efficiency and renewable energy beyond those that would occur in a "business-as-usual" (BAU) scenario. While EPA does not suggest that "business-as-usual" projects be excluded, they do recommend encouraging new projects, and thus suggest that a state either (1) set a larger pool size to provide enough room for both new and BAU projects in the set-aside, or (2) for states with a small pool size, use a factor that compensates for a portion of the estimated BAU activity on a project-by-project basis. ${ }^{1}$

Because the program does not go into effect until 2003, EPA recommends that states award allowances for EE/RE projects that are "initiated and come on-line" during the early action period of approximately three years from 2000-2003.

The length of an award can be one year or it can be for multiple control periods. EPA argues that because reductions achieved through $\mathrm{EE} / \mathrm{RE}$ projects tend to be persistent in nature, they are

\footnotetext{
${ }^{1}$ A compensation factor of $75 \%$ has been officially established in the second EPA guidance document, issued in April 2000 (EPA 2000).
} 
expected to provide long-term air quality benefits and may thus qualify for allowances awarded on a multi-year basis. EPA recommends three-year awards.

EPA has further recommendations for over-subscription and under-subscription of the pool, and suggests that one way of dealing with over-subscription is to use a first come first served method. It also recommends that states with over-subscription problems consider expanding the set-aside for the following year. Under-subscription can be resolved by (1) auctioning the unclaimed allowances; (2) distributing the unclaimed allowances to core sources or others interested; (3) distributing the unclaimed allowances to existing set-aside projects on a pro-rata basis; (4) retiring the unclaimed allowances; and (5) allocating the unused allowances in the next summer ozone period. ${ }^{2}$

\subsection{NEW YORK'S IMPLEMENTATION}

Even though the NOx SIP Call's status is at present uncertain, some states have decided to proceed with implementing it. New York is at the forefront of this effort, and appears to be the only state with an 'up and running' pilot program involving the set-aside. Massachusetts has decided on a 5\% set-aside, and Maryland, New Jersey, and Indiana are at various stages of the regulatory process in determining a percentage for the EE/RE set-aside and in coming to agreement on the overall program. $^{3} \quad$ Illinois and Missouri are two other states considering the set-aside (personal communication, Jeffrey Genzer, NASEO, September 1999). The 13 states in the OTR are, in any case, committed to come down to $0.15 \mathrm{lbs} / \mathrm{mm}$ Btu of NOx as part of Phase II of the September '94 MOU, by May 2003. This NOx level, also recommended by OTAG for utilities, was used by EPA as a basis for calculating state NOx budgets in the SIP Call.

New York, certainly, has proceeded with implementing the set-aside as preparation for Phase III of the MOU. The New York State Department of Environmental Conservation (NYSDEC) - the overall administrative body for the NOx emissions reduction programs - awarded the New York State Energy Research and Development Authority (NYSERDA) 115 tons of NOx allowances for energy efficiency projects (although not for renewable energy at this stage). NYSERDA began distributing them for qualified EE programs in 1998, to end in 2003, so that they will achieve $3 \%$ (New York's designated EE/RE set-aside percentage) of the state's allotted NOx reductions using these 115 allowances. They also propose to have measurement and verification (M\&V) protocols completed by the time Phase III begins (personal communication, Peter Smith, NYSERDA, September 21, 1999).

\footnotetext{
${ }^{2}$ Design elements outlined in the second EPA guidance document include EPA's recommendations on: when the allowance awards will be made (timing of awards); how and when to apply for awards and what is needed in the application; how to measure and verify results in terms of energy saved or displaced; how to translate project results (energy saved or displaced) into emissions; and how to direct set-aside allowance awards to "new" projects.

${ }^{3}$ New Jersey's EE/RE allocation derives from a longer-standing program and does not include a specific set-aside percentage but rather an open-door policy to all projects that can demonstrate energy savings; with the relatively small magnitudes of the savings from these projects compared to the emissions of the major, fixed-site emitters, no problems in overall permit allocations are foreseen from this policy.
} 
While the regulations outlining the details of the energy efficiency/renewable energy set-aside program $^{4}$ - to be implemented in May 2003 — do not offer implementation details, NYSERDA has indicated that the guidance document dealing with issues of $\mathrm{M} \& \mathrm{~V}$ protocols will require 1) energy savings to be metered savings mainly due to concerns with double counting, and 2) NOx emissions reductions to be in whole ton increments. These factors, according to NYSERDA, will make it difficult for residential energy programs to be eligible for NOx allowances. Thus, while the application of NOx allowances to weatherization programs in New York may not, at present, be encouraged, it may prove worthwhile for other state energy programs that can show metered savings as well as higher overall Btu numbers.

\footnotetext{
${ }^{4}$ Proposal referred to in the June 30, 1999 New York State Register, Part 204, Section 5.3 (f).
} 


\section{NOx EMISSIONS REDUCTIONS AND WEATHERIZATION}

Thus far, the focus of Weatherization has been on improving the heating and cooling efficiency of low-income families' homes, thereby lowering their energy bills and improving their health and safety. While these efficiency measures have, in the past, made contributions to reductions in NOx emissions, the move to a "whole house" approach—expanding to include the retrofitting of other energy efficient appliances, such as refrigerators, freezers, air conditioners, water heaters, and lighting change-outs - would greatly increase the potential for electricity-related energy savings, and thus NOx emissions savings. Current weatherization measures are weighted heavily toward building envelope upgrades and water heater insulation, both of which rely to significant extents on power sources other than electricity in many regions of the country. However, electricity generation is the primary NOx emitter, so the current examination of the potential for the Weatherization Assistance Program to reduce NOx emissions focuses on electric appliance upgrades which are not routine weatherization measures. This procedure yields an upper bound on the emission savings that weatherization could provide.

Preliminary calculations of NOx emissions reductions through appliance upgrades indicate that noticeable savings are possible (see Appendix I for NOx emission savings for all 22 states and the District of Columbia included in the original NOx SIP Call, and Appendix II for an explanation of the calculations). ${ }^{5}$ In Indiana for instance - in the Midwest region-an appliance efficiency upgrade of a refrigerator, a separate freezer unit, a water-heater, a room air-conditioner and a lighting changeout in 4,647 homes (the approximate number weatherized in $1998^{6}$ ) would result in annual NOx emission savings of 23 tons. Doing an appliance upgrade in Illinois for 11,113 houses, also in the Midwest, results in 53 tons of savings annually. In Massachusetts-in the New England regiona similar upgrade in 6,203 homes would yield only 10 tons in annual savings. Such an upgrade in Virginia, in the Southwest, of less than half the number of homes in Massachusetts (3,006 homes) would also yield 10 tons of NOx emissions savings annually. Differences in fuel mixes, and in coal characteristics, produce the differences observed across states in NOx emission savings per house weatherized.

\footnotetext{
${ }^{5}$ Greenhouse Gas Emissions Savings Attributed to Appliance Retrofits: 1998-2020, Microsoft Excel 97, model being developed for Oak Ridge National Laboratory, June 1999 (see Appendix II for details).

${ }^{6}$ See Appendix III for calculations.
} 
Table 1: Nitrogen Oxide (NOx) emissions saved in homes weatherized in 1998, in pounds

\begin{tabular}{|c|c|c|c|c|c|c|c|c|}
\hline $\begin{array}{l}\text { Type of } \\
\text { appliance } \\
\text { upgraded }\end{array}$ & $\begin{array}{l}\text { Indiana/ } \\
\text { ECAR }\end{array}$ & $\begin{array}{l}\text { Ohio/ } \\
\text { ECAR }\end{array}$ & $\begin{array}{l}\text { Massachu } \\
\text { setts/ } \\
\text { NEPCC- } \\
\text { NE }\end{array}$ & $\begin{array}{l}\text { Virginia/ } \\
\text { SERC- } \\
\text { excludin } \\
\text { g FL) }\end{array}$ & $\begin{array}{l}\text { Maryland/ } \\
\text { MAAC }\end{array}$ & $\begin{array}{l}\text { Pennsyl } \\
\text { vania/ } \\
\text { MAAC }\end{array}$ & $\begin{array}{l}\text { New } \\
\text { York/ } \\
\text { NEPCC } \\
\text {-NY }\end{array}$ & $\begin{array}{l}\text { Illinois/ } \\
\text { MAIN }\end{array}$ \\
\hline Refrigerator & 8,992 & 25,789 & 3,852 & 3,811 & 1,458 & 7,800 & 10,283 & 20,223 \\
\hline Lighting & 5,206 & 14,932 & 2,230 & 2,207 & 3,172 & 4,516 & 5,954 & 11,709 \\
\hline Freezers & 4,360 & 12,504 & 1,867 & 1,848 & 707 & 3,782 & 4,986 & 9,805 \\
\hline $\begin{array}{l}\text { Electric } \\
\text { Water } \\
\text { Heating }\end{array}$ & 31,032 & 89,003 & 13,292 & 13,153 & 5,031 & 26,918 & 35,488 & 69,792 \\
\hline $\begin{array}{l}\text { Room Air } \\
\text { Conditioner }\end{array}$ & 1,938 & 5,557 & 830 & 821 & 314 & 1,681 & 2,216 & 4,358 \\
\hline $\begin{array}{l}\text { Total NOx } \\
\text { saved (lbs.) }\end{array}$ & 51,528 & 147,785 & 22,071 & 21,840 & 10,682 & 44,697 & 58,927 & 115,887 \\
\hline $\begin{array}{l}\text { Total NOx } \\
\text { saved } \\
\text { (metric tons) }\end{array}$ & 23 & 67 & 10 & 10 & 5 & 20 & 27 & 53 \\
\hline $\begin{array}{l}\text { Number of } \\
\text { homes } \\
\text { weatherized } \\
\text { in } 1998\end{array}$ & 4,647 & 13,328 & 6,203 & 3,006 & 1,786 & 9,557 & 17,569 & 11,113 \\
\hline
\end{tabular}




\section{SUMMARY OF FINDINGS}

The savings picture reported in Chapter 4 suggests that the fuel mix of a region's electricity generation is a major factor influencing the NOx emission savings in a state. Regions with a higher concentration of coal in their electric fuel mix will tend to have much higher savings. States like Massachusetts, in the New England region, will have a lower savings rate as a result of the lower coal content in their fuel mix. And states in the middle of the country, like Virginia in the Southeast and Pennsylvania in the Mid-Atlantic, will have a savings rate somewhere between the Midwest states and the New England states.

Another defining factor is, of course, the number of homes upgraded. In the Mid-Atlantic region, an upgrade in Pennsylvania of 9,557 homes results in roughly 6.7 tons of savings during the summer ozone season, and an upgrade of 1,786 homes in Maryland (in the same electric reliability region) returns 1.7 tons of savings. Similarly, upgrading 4,647 homes in Indiana yields 7.6 tons of savings, whereas in Ohio (same region), an upgrade of 13,328 homes results in 22.3 tons of summer NOx emissions savings.

At a rate of $\$ 3,000$ per ton of NOx during the summer season, a whole-house retrofit of 4,647 homes in Indiana would yield about $\$ 21,000$ to the Weatherization Program, if they traded their allowances in the open market for NOx allowances. Ohio would earn $\$ 66,000$, Illinois would earn $\$ 51,000$, Pennsylvania $\$ 18,000$, Massachusetts $\$ 9,000$ and Maryland $\$ 3,000$. Because the smallest unit that NOx trading can be done in is tons, a threshold number of homes would be required to make it worthwhile for a state weatherization program to apply for NOx allowances.

Other factors to consider are EPA's recommendations for selecting EE/RE projects eligible for the set-aside. One recommendation clearly favors "new" projects, by suggesting that a compensation factor be used when calculating NOx allowances for BAU projects, which Weatherization would appear to be.

Finally, much will depend on how New York and the other states now considering the setaside implement their programs. If other states follow in New York's steps and require metered energy savings, it may be more difficult for Weatherization to qualify. 


\section{STATE WEATHERIZATION PROGRAMS' BENEFITS IN THE NOx TRADABLE PERMIT PROGRAM: OPPORTUNITIES AND LIMITATIONS}

The financial attractiveness of the NOx SIP EE/RE set-aside for the Weatherization Programs varies considerably across states, as Table 2 shows. First, the restriction of emission savings from the programs to the summer ozone season (one-third of a year) eliminates virtually all of the heating savings from weatherized homes, which is a major element of that program. The remaining annual savings from various appliance and other equipment efficiency improvements must be reduced by two-thirds. The NOx tonnages derived from those retrofits, valued at an estimated average of $\$ 3,000$ per ton (rounded to the lower full ton, in accordance with the regulation), yields more than $\$ 50,000$ in only two of the states, even when weatherization measures are slanted more toward electric appliance replacement than is ordinarily the case in current practice. Even these sums are very small percentages of those states' recent Weatherization budgets- $1 / 4 \%$ of 1998 expenditures, amounting to 33 and $25 \frac{1}{2}$ additional houses weatherized in the two states. Whether the application and reporting efforts involved to secure these additional funds are worth a state agency's time is a question for individual states to answer according to their own situations.

Second, monitoring and verification $(\mathrm{M} \& \mathrm{~V})$ raise some further issues. While the U.S. EPA has not outright disqualified projects for permits if their M\&V cannot be directly metered, its second guidance document suggests a discounting of estimated savings. The third guidance document will offer more specific detail in recommended $M \& V$ discounting schemes. New York has excluded from its permit program projects whose savings cannot be directly metered, although this sanction may be subject to negotiation for a program such as Weatherization, which has an extensive track record of evaluation.

Third, beyond the monitoring and verification issue, EPA has expressed the nonbinding recommendation that states favor "new" projects, "new" being defined as activities that help innovate new technologies, but excluding projects whose energy and emission savings derive from management and operational improvements. Although the energy and emission savings of weatherization projects have been subjected to extensive evaluation efforts which have returned solid evidence of the savings they can supply, it is not clear that weatherization activities would qualify for EPA's definition of "new" projects. EPA does allow for inclusion of what it calls "business-as-usual" projects, but with their emission savings discounted by as much as $25 \%$. EPA's reasoning appears to be that it wants to exclude projects that would have been undertaken anyway from getting what would effectively be a rebate in the form of marketable emission permits. Under this interpretation of "new," weatherization programs could offer the argument that the budget augmentations deriving from marketed emission permits would permit weatherization of houses that could not have been weatherized otherwise, given their legislated funding. Only if those agencies' line-item funding were reduced by the amount of their income from emission permit sales could the objection be made that weatherization projects were simply using permit income to fund what would have been undertaken anyway. It is unlikely that legislatures and state agencies would consider it worth their effort to reduce the budgets of these agencies by such small, and unpredictable, amounts. 
Table 2. Financial benefits to State Weatherization Programs from NOx permit sales

\begin{tabular}{|c|c|c|}
\hline $\begin{array}{l}\text { Summer NOx savings } \\
\text { (tons, rounded to lower } \\
\text { whole ton) }\end{array}$ & $\begin{array}{l}\text { Income from sale of } \\
\text { emission permits @ } \\
\$ 3,000 / \text { ton }\end{array}$ & $\begin{array}{l}\text { Permit sale income } \\
\text { as \% of } 1998 \\
\text { weatherization } \\
\text { expenditures }\end{array}$ \\
\hline
\end{tabular}

Indiana

Kentucky

Michigan

Ohio

West Virginia

Illinois

Wisconsin

Missouri

District of

Columbia

Delaware

Maryland

New Jersey

Pennsylvania

Connecticut

Massachusetts

Rhode Island

New York

Alabama

Georgia

North Carolina

South Carolina

Tennessee

Virginia

\section{7 \\ 4 \\ 7}

22

2

17

8

3

0

1

1

3

6

0

3

0

9

1

3

6

1

2

3
21,000

12,000

21,000

66,000

6,000

51,000

24,000

9,000

$0.19 \%$

Incremental $h$ o $m$ e $s$ weatherized with permit income (@ $\$ 2,000 /$ unit)

10.5

6

10.5

33

2

25.5

12

4.5

3,000

$0.21 \%$

1.5

3,000

$0.08 \%$

1.5

9,000

$0.11 \%$

4.5

18,000

$0.09 \%$

9

9,000

$0.07 \%$

4.5

27,000

$0.08 \%$

13.5

3,000

$0.13 \%$

1.5

9,000

$0.16 \%$

4.5

18,000

$0.18 \%$

9

3,000

$0.11 \%$

1.5

6,000

$0.13 \%$

3

9,000

$0.15 \%$

4.5 


\section{REFERENCES}

Koomey, J., C. Atkinson, A. Meier, J. McMahon, S. Boghosian, B. Atkinson, I. Turiel, M.D. Levine, B. Nordman, and P. Chan. 1991. "The Potential for Electricity Efficiency Improvements in the U.S. Residential Sector.” LBL-30477, Berkeley, Calif.: Lawrence Berkeley National Laboratory, July.

Letzelter, James C., and Marc W. Chupka. 1999. "Surviving the SIP Call: Fossil Plant Economics Under NOx Control,” Public Utilities Fortnightly Vol. 137, No. 9 (May 1).

New York State Register, Part 204, Section 5.3 (f), June 30, 1999.

U.S. Environmental Protection Agency (EPA). 1997. "Ozone Transport Commission NOx Budget Program: An Overview." EPA Fact Sheet, May.

U.S. Environmental Protection Agency (EPA), Office of Atmospheric Programs, Office of Air and Radiation. 1999. "Guidance on Establishing an Energy Efficiency and Renewable Energy (EE/RE) Set-Aside in the NOx Budget Trading Program." March.

U.S. Environmental Protection Agency (EPA), Office of Atmospheric Programs, Office of Air and Radiation. 2000. "Creating an Energy Efficiency and Renewable Energy Set-Aside in the NOX Budget Trading Program: Designing the Administrative and Quantitative Elements." EPA-430-K-00004. April.

U.S. Department of Energy, Energy Information Administration (EIA). 1998 Annual Energy Outlook 1998 (AEO98). DOE/EIA-0383(1998). Washington, D.C.: U.S. Government Printing Office, December. 
Appendix I: Nitrogen Oxide (NOX) Emissions Savings for a Full Year

Applicable National Electric Reliability Council (NERC) regions

East Central Area (ECAR)

Mid-Atlantic Area Council (MAAC)

Mid-America Interconnected Network (MAIN)

Northeast Power Coordinating Council/New York (NEPCC-NY)

Northeast Power Coordinating Council/New England Power Exchange (NEPCC-NE)

Southeastern Electric Reliability Council/Excluding Florida (SERC-Excluding FL)

\begin{tabular}{|c|c|c|c|c|c|}
\hline $\begin{array}{l}\text { Type of } \\
\text { appliance } \\
\text { upgraded }\end{array}$ & $\begin{array}{l}\text { Indiana } \\
\text { (ECAR) }\end{array}$ & $\begin{array}{l}\text { Kentucky } \\
\text { (ECAR) }\end{array}$ & $\begin{array}{l}\text { Michigan } \\
\text { (ECAR) }\end{array}$ & $\begin{array}{l}\text { Ohio } \\
\text { (ECAR) }\end{array}$ & $\begin{array}{l}\text { West } \\
\text { Virginia } \\
\text { (ECAR) }\end{array}$ \\
\hline Refrigerator & 8,992 & 4,772 & 8,142 & 25,789 & 2,699 \\
\hline Lighting & 5,206 & 2,763 & 4,714 & 14,932 & 1,563 \\
\hline Freezers & 4,360 & 2,314 & 3,948 & 12,504 & 1,309 \\
\hline $\begin{array}{l}\text { Electric } \\
\text { Water } \\
\text { Heating }\end{array}$ & 31,032 & 16,468 & 28,101 & 89,003 & 9,316 \\
\hline $\begin{array}{l}\text { Room Air } \\
\text { Conditioner }\end{array}$ & 1,938 & 2,426 & 1,755 & 5,557 & 582 \\
\hline $\begin{array}{l}\text { Total Nox } \\
\text { saved (lbs.) }\end{array}$ & 51,528 & 28,743 & 46,660 & 147,785 & 15,469 \\
\hline $\begin{array}{l}\text { Total Nox } \\
\text { saved (metric } \\
\text { tons) }\end{array}$ & 23 & 13 & 21 & 67 & 7 \\
\hline $\begin{array}{l}\# \text { of homes } \\
\text { weatherized } \\
\text { in } 1998\end{array}$ & 4,647 & 2,466 & 4,208 & 13,328 & 1,395 \\
\hline
\end{tabular}


Type of appliance

upgrade

$\begin{array}{llll}\text { Refrigerator } & 20,223 & 9,292 & 4,355 \\ \text { Lighting } & 11,709 & 5,380 & 2,521 \\ \text { Freezers } & 9,805 & 4,505 & 2,111 \\ \begin{array}{l}\text { Electric Water } \\ \text { Heating }\end{array} & 69,792 & 32,067 & 15,029 \\ \begin{array}{l}\text { Room Air } \\ \text { Conditioner }\end{array} & 4,358 & 2,002 & 938 \\ \begin{array}{l}\text { Total Nox saved } \\ \text { (lbs.) }\end{array} & 115,887 & 53,246 & 24,954 \\ \begin{array}{l}\text { Total Nox saved } \\ \text { (metric tons) }\end{array} & \mathbf{5 3} & & \mathbf{1 1} \\ \begin{array}{l}\text { \# of homes } \\ \text { weatherized in } \mathbf{1 9 9 8}\end{array} & 11,113 & \mathbf{2 4} & \\ \end{array}$

Wisconsin (MAIN) Missouri (MAIN)

Illinois (MAIN) 


\begin{tabular}{|c|c|c|c|c|c|}
\hline $\begin{array}{l}\text { Type of } \\
\text { appliance } \\
\text { upgrade }\end{array}$ & $\begin{array}{l}\text { District of } \\
\text { Columbia } \\
\text { (MAAC) }\end{array}$ & $\begin{array}{l}\text { Delaware } \\
\text { (MAAC) }\end{array}$ & $\begin{array}{l}\text { Maryland } \\
\text { (MAAC) }\end{array}$ & $\begin{array}{l}\text { New Jersey } \\
\text { (MAAC) }\end{array}$ & $\begin{array}{l}\text { Pennsylvania } \\
\text { (MAAC) }\end{array}$ \\
\hline Refrigerator & 467 & 577 & 1,458 & 3,431 & 7,800 \\
\hline Lighting & 270 & 334 & 3,172 & 1,987 & 4,516 \\
\hline Freezers & 226 & 280 & 707 & 1,664 & 3,782 \\
\hline $\begin{array}{l}\text { Electric } \\
\text { Water } \\
\text { Heating }\end{array}$ & 1,611 & 7,485 & 5,031 & 11,841 & 26,918 \\
\hline $\begin{array}{l}\text { Room Air } \\
\text { Conditioner }\end{array}$ & 101 & 124 & 314 & 739 & 1,681 \\
\hline $\begin{array}{l}\text { Total Nox } \\
\text { saved (lbs.) }\end{array}$ & 2,675 & 8,800 & 10,682 & 19,662 & 44,697 \\
\hline $\begin{array}{l}\text { Total Nox } \\
\text { saved } \\
\text { (metric tons) }\end{array}$ & 1 & 4 & 5 & 9 & 20 \\
\hline $\begin{array}{l}\text { \# of homes } \\
\text { weatherized } \\
\text { in } 1998\end{array}$ & 572 & 707 & 1,786 & 4,204 & 9,557 \\
\hline
\end{tabular}




\begin{tabular}{lllll}
$\begin{array}{l}\text { Type of } \\
\text { appliance } \\
\text { upgrade }\end{array}$ & $\begin{array}{l}\text { Connecticut } \\
\text { (NEPCC-NE) }\end{array}$ & $\begin{array}{l}\text { Massachusetts } \\
\text { (NEPCC-NE) }\end{array}$ & $\begin{array}{l}\text { Rhode Island } \\
\text { (NEPCC-NE) }\end{array}$ & $\begin{array}{l}\text { New York } \\
\text { (NEPCC-NY) }\end{array}$ \\
$\begin{array}{l}\text { Refrigerator } \\
\text { Lighting }\end{array}$ & 739 & 3,852 & 502 & 10,283 \\
$\begin{array}{l}\text { Freezers } \\
\text { Electric } \\
\text { Water }\end{array}$ & 2,558 & 2,230 & 291 & 5,954 \\
$\begin{array}{l}\text { Heating } \\
\text { Room Air } \\
\text { Conditioner }\end{array}$ & 159 & 1,867 & 244 & 4,986 \\
$\begin{array}{l}\text { Total Nox } \\
\text { saved (lbs.) }\end{array}$ & 4,234 & 13,292 & 1,734 & 35,488 \\
$\begin{array}{l}\text { Total Nox } \\
\text { saved } \\
\text { (metric tons) }\end{array}$ & $\mathbf{2}$ & 830 & & \\
$\begin{array}{l}\text { \# of homes } \\
\text { weatherized } \\
\text { in 1998 }\end{array}$ & 1,190 & 22,071 & 108 & 2,216 \\
\hline
\end{tabular}




\begin{tabular}{|c|c|c|c|c|c|c|}
\hline $\begin{array}{l}\text { Type of } \\
\text { appliance } \\
\text { upgrade }\end{array}$ & $\begin{array}{l}\text { Alabama } \\
\text { (SERC- } \\
\text { excluding } \\
\text { FL) }\end{array}$ & $\begin{array}{l}\text { Georgia } \\
\text { (SERC - } \\
\text { excluding } \\
\text { FL) }\end{array}$ & $\begin{array}{l}\text { North } \\
\text { Carolina } \\
\text { (SERC - } \\
\text { excluding } \\
\text { FL) }\end{array}$ & $\begin{array}{l}\text { South } \\
\text { Carolina } \\
\text { (SERC- } \\
\text { excluding } \\
\text { FL) }\end{array}$ & $\begin{array}{l}\text { Tennessee } \\
\text { (SERC- } \\
\text { excluding } \\
\text { FL) }\end{array}$ & $\begin{array}{l}\text { Virginia } \\
\text { (SERC- } \\
\text { excluding } \\
\text { FL) }\end{array}$ \\
\hline Refrigerator & 1,473 & 3,677 & 6,344 & 1,663 & 3,006 & 3,811 \\
\hline Lighting & 853 & 2,129 & 3,673 & 963 & 1,741 & 2,207 \\
\hline Freezers & 714 & 1,783 & 3,076 & 807 & 1,458 & 1,848 \\
\hline $\begin{array}{l}\text { Electric } \\
\text { Water } \\
\text { Heating }\end{array}$ & 5,085 & 12,689 & 21,896 & 5,741 & 10,375 & 13,153 \\
\hline $\begin{array}{l}\text { Room Air } \\
\text { Conditioner }\end{array}$ & 749 & 1,869 & 3,226 & 846 & 1,528 & 821 \\
\hline $\begin{array}{l}\text { Total Nox } \\
\text { saved (lbs.) }\end{array}$ & 8,874 & 22,147 & 44,559 & 10,020 & 18,108 & 21,840 \\
\hline $\begin{array}{l}\text { Total Nox } \\
\text { saved } \\
\text { (metric } \\
\text { tons) }\end{array}$ & 4 & 10 & 20 & 5 & 8 & 10 \\
\hline $\begin{array}{l}\# \text { of homes } \\
\text { weatherized } \\
\text { in } 1998\end{array}$ & 1,162 & 2,900 & 5,004 & 1,312 & 2,371 & 3,006 \\
\hline
\end{tabular}




\section{Appendix II: Methodology for Calculation of Nitrogen Oxide Emissions}

\section{a) NOx emissions calculations}

The NOx emissions are calculated using a spreadsheet model based primarily on the emissions data from the Annual Energy Outlook 1998 (AEO98). Here, the Energy Information Administration (EIA), using the NEMS model, projects electric generation and carbon, sulfur dioxide and nitrogen dioxide emissions based on a projected fuel mix for electricity generation, from 1996 to 2020. These data tables can be found as supplements to AEO98 on the EIA website (http://www.eia.doe.gov), although it is not included in the printed report.

NEMS projections are done on the basis of the thirteen (13) NERC regions and our spreadsheet uses the same regional categories:

East Central Area

Electric Reliability Council of Texas

Mid-Atlantic Area Council

Mid-America Interconnected Network

Mid-Continent Area Power Pool

Northeast Power Coordinating Council/New York

Northeast Power Coordinating Council/New England Power Exchange

Southeastern Electric Reliability Council/Florida

Southeastern Electric Reliability Council/Excluding Florida

Southwest Power Pool

Western Systems Coordinating Council/NWP

Western Systems Coordinating Council/RA

Western Systems Coordinating Council/CNV

Consider, for instance, calculating NOx emissions saved in a state in the New England region (Maine, for example), in 1998, by a refrigerator upgrade in a single family home.

NEMS' projections of total electricity generated in each of the NERC regions from 1996-2020 are in billion $\mathrm{kWh}$ and its projections of total carbon $(\mathrm{C})$, sulfur dioxide $\left(\mathrm{SO}^{2}\right)$, and nitrogen oxide (NOx) emissions are in million short tons.

Using these data, we first calculate the number of NOx emissions (in short tons) per MWh generated. For the Northeast Coordinating Council/New England Power Exchange, the total electricity generation would be: 102.84 billion $\mathrm{kWh}$. The NOx emissions projected: 0.1 million short tons.

Thus the NOx emissions for the region, in tons per MWh, was: 0.000972.

The refrigerator upgrade gives an energy savings of $297 \mathrm{kWh}$. Taking into consideration transmission and distribution (T\&D) losses of about $7.5 \%$ (therefore multiply energy savings by 1.075), we calculate the energy savings to be $319.275 \mathrm{kWh}$. 
This amount is then multiplied by the NOx emissions per MWh of electricity generated to obtain the emission savings. The resulting number is divided by 1000 (because energy savings are in $\mathrm{kWh}$ ) and multiplied by 2000 to get the emissions saved in lbs.

Thus the NOx emissions savings in this instance would be: $0.000972 * 319.275 * 2000 / 1000=0.621 \mathrm{lbs}$.

For 2,059 homes, the savings would be $0.000972 * 319.275 * 2,059 * 2000 / 1000=1278$ lbs of NOx.

A cumulative savings number, from 1998-2020, can also be calculated using the spreadsheet, which automatically adds up all the savings from each year from 1998 to 2020.

\section{b) Appliance Upgrades and Energy Savings}

The other data source of importance in this spreadsheet is the energy savings due to appliance efficiency upgrades. These were obtained from three different sources:

* For refrigerators, freezers, electric water heaters and electric dryers, the data were obtained from Appendix C of "Scenarios for U.S. Carbon Reductions", the five-laboratory study commissioned by DOE, and can be obtained from Jonathan Koomey at the Lawrence Berkeley National Laboratory, email: jgkoomey@lbl.gov.

* Figures for the lighting upgrade, and for the electric washers, were obtained from the draft Buildings Module spreadsheet developed by Skip Laitner and ORNL for calculating energy savings in buildings through appliance upgrades. Although this module is state-based, the energy savings calculated for dryers does not change with each state, and the savings for lighting change-outs in different states vary by negligible amounts. Consequently, we felt comfortable using the energy savings from a single family home in a moderate climate region for our purposes here.

* Finally, the figures for central and room air-conditioning in single family homes in the North and South were obtained from as yet-unpublished data compiled and developed into a spreadsheet by Jonathan Koomey at el. at the Lawrence Berkeley National Laboratory. He sent this to us via email. This is being done as a follow-up to the numbers in Koomey et al. 1991. Again, the update can be obtained from Jonathan Koomey. 
Appendix III: Number of Homes Weatherized in 1998

\begin{tabular}{|c|c|c|c|c|c|c|c|}
\hline & $\begin{array}{l}\text { Alabama } \\
\text { (SERC) }\end{array}$ & $\begin{array}{l}\text { Connecticut } \\
\text { (NEPCC) }\end{array}$ & $\begin{array}{l}\text { District of } \\
\text { Columbia } \\
\text { (MAAC) }\end{array}$ & $\begin{array}{l}\text { Delaware } \\
\text { (MAAC) }\end{array}$ & $\begin{array}{l}\text { Georgia } \\
\text { (SERC) }\end{array}$ & $\begin{array}{l}\text { Illinois } \\
\text { (MAIN) }\end{array}$ & $\begin{array}{l}\text { Kentucky } \\
\text { (ECAR) }\end{array}$ \\
\hline $\begin{array}{l}\text { Estimated } 1998 \\
\text { expenditures on } \\
\text { weatherization }\end{array}$ & $\$ 2,324,464$ & $\$ 2,380,495$ & $\$ 1,143,372$ & $\$ 1,413,092$ & $\$ 5,800,522$ & $\$ 22,225,927$ & $\$ 4,931,095$ \\
\hline \multirow[t]{2}{*}{$\begin{array}{l}\text { Number of homes } \\
\text { weatherized in } \\
1_{1998^{8}}\end{array}$} & 1,162 & 1,190 & 572 & 707 & 2,900 & 11,113 & 2,466 \\
\hline & $\begin{array}{l}\text { Massachusetts } \\
\text { (NEPCC) }\end{array}$ & $\begin{array}{l}\text { Maryland } \\
\text { (MAAC) }\end{array}$ & $\begin{array}{l}\text { Michigan } \\
\text { (ECAR) }\end{array}$ & $\begin{array}{l}\text { Missouri } \\
\text { (MAIN) }\end{array}$ & $\begin{array}{l}\text { New Jersey } \\
\text { (MAAC) }\end{array}$ & $\begin{array}{l}\text { North } \\
\text { Carolina } \\
\text { (SERC) }\end{array}$ & Ohio (ECAR) \\
\hline $\begin{array}{l}\text { Estimated } 1998 \\
\text { expenditures on } \\
\text { weatherization }\end{array}$ & $\$ 12,405,607$ & $\$ 3,571,644$ & $\$ 8,415,861$ & $\$ 4,786,047$ & $\$ 8,408,439$ & $\$ 10,008,800$ & $\$ 26,656,504$ \\
\hline $\begin{array}{l}\text { Number of } \\
\text { homes } \\
\text { weatherized in } \\
1998\end{array}$ & 6,203 & 1,786 & 4,208 & 2,393 & 4,204 & 5,004 & 13,32 \\
\hline
\end{tabular}

${ }^{7}$ Weatherization Funding Survey 1998, compiled by the Weatherization Assistance Program Technical Assistance Center, 444 North Capitol Street, NW, Suite 221, Washington, DC 20001.

${ }^{8}$ Calculated by dividing total weatherization program dollars spent in 1998 by $\$ 2,000$, assuming a per household expenditure of $\$ 2,000$. 


$\begin{array}{lllllll} & \begin{array}{l}\text { Pennsylvania } \\ \text { (MAAC) }\end{array} & \begin{array}{l}\text { Rhode } \\ \text { Island } \\ \text { (NEPCC) }\end{array} & \begin{array}{l}\text { South } \\ \text { Carolina } \\ \text { (SERC) }\end{array} & \begin{array}{l}\text { Tennessee } \\ \text { (SERC) }\end{array} & \begin{array}{l}\text { Virginia } \\ \text { (SERC) }\end{array} & \begin{array}{l}\text { Wisconsin } \\ \text { (MAIN) }\end{array} \\ \begin{array}{l}\text { Estimated 1998 } \\ \text { expenditures on } \\ \text { weatherization }\end{array} & \$ 19,114,344 & \$ 1,617,703 & \$ 2,623,000 & \$ 4,742,141 & \$ 6,011,884 & \$ 10,212,334 \\ \begin{array}{l}\text { Number of } \\ \text { homes } \\ \text { weatherized in }\end{array} & 9,557 & 809 & 1,312 & 2,371 & 3,006 & 5,106 \\ \mathbf{1 9 9 8} & & & & & & \end{array}$

$\begin{array}{lll}\begin{array}{l}\text { Indiana } \\ \text { (ECAR) }\end{array} & \begin{array}{l}\text { New York } \\ (\text { NEPCC/NY) }\end{array} & \begin{array}{l}\text { West Virginia } \\ \text { (ECAR) }\end{array}\end{array}$

Estimated 1998

$\$ 9,293,488 \quad \$ 35,137,445 \quad \$ 2,789,672$

expenditures on

weatherization

Number of homes

4,647

17,569

1,395

weatherized in

1998 